\title{
Pros And Cons Of E-Commerce Taxation
}

Mark G. Simkin, (E-mail: simkin@equinox.unr.edu), University of Nevada, Reno Graham W. Bartlett, (E-mail: ecbartlett@aol.com), University of Nevada, Reno J. P. Shim, (E-mail: jshim@ cobilan.msstate.edu), Mississippi State University

\begin{abstract}
Tax policies affecting the Internet have important implications for the continued growth of ecommerce and trade, as well as the future of both corporate and individual privacy. This paper explores some of the issues concerning both domestic and international Internet taxation, reviews the current Internet Tax Freedom Act, analyzes e-commerce and its effects on taxing systems throughout the world, and provides arguments for and against e-commerce taxation and regulation.
\end{abstract}

\section{Introduction}

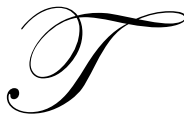

he Internet is used by more than 332 million around the world and is perhaps the most advanced and useful medium of commerce and communications yet created. (Nau Internet, '00) The increasing rate of international business-to-business and business-to-consumer transactions over the Internet raises questions about collecting taxes on sales. In addressing whether and how Internet commerce should be subject to taxes, countries face the difficult challenge of respecting the laws of other countries. In order to investigate the importance of these concerns, it is necessary to examine: (1) how the rise of Internet sales thus far has altered sales tax collections and (2) the evidence regarding the predicted future collection of these taxes.

According to the United States Department of Commerce Census Bureau, 1999 online retail sales equaled $\$ 5.3$ billion. As large as this number is, these sales constitute only .64\% of total retail sales during the fourth quarter of 1999. (U.S. Dept. of Commerce, Bureau of Census, Mar. '00) In this estimate, the term "retail sales" included only sales of tangible goods (e.g., books, computer equipment, furniture and clothing) and does not include sales of services (e.g., financial services, travel, and entertainment).

Inasmuch as Internet sales are such a small percentage of overall retail sales, why is Internet taxation even an issue? Perhaps the most important argument is the fear of losing large amounts of future tax revenues as Internet commerce begins to replace, rather than augment, main street sales. Other concerns include the impact of Internet commerce on international trade, the issues that arise when taxable, digital products are "shipped" over the Internet, the fact that the inconsistent Internet tax policies encourage offshore havens for avoiding tax liabilities, and many privacy issues.

How realistic or material are these concerns? The purpose of this paper is to examine Internet tax issues and the implications of the growth of e-commerce on taxing systems worldwide. Thus, the paper reviews the basic principles that govern taxes throughout the world, explores the questions raised by applying taxes on Internet sales, and identifies some of the problems resulting from e-commerce taxation. Section II of this paper examines domestic Internet taxation, especially state-based sales and use taxes. Section III explores the international e-commerce taxation, focusing on such issues as the proxy status of web servers, international tax havens, value added taxes, and tariffs. The information contained in this paper will keep IT professionals, educators, tax attorneys, and accountants in the field of tax law, knowledgeable of the issues posed by this topic and their many potential implications.

Readers with comments or questions are encouraged to contact the authors via email.

\section{Domestic Issues}

In the United States, retail sales to consumers are subject to two primary taxes: sales taxes and use taxes. 
Sales taxes are imposed at the time that a consumer purchases a good or service, and where possible, are passed on to the consumer as add-on charges. In contrast, use taxes are most commonly due when an item is purchased from a business in another state and the business does not have physical presence, or "nexus," in the consumer's state for the sale to be subjected to sales tax. (Quill Corp. v. N. Dakota, 92') When a consumer purchases an item and the sales tax is not collected, the consumer in those states with use taxes is responsible for paying the use tax according to the location of consumption of the item. Most Internet shoppers violate this law simply because they know not of, or do not understand, that they must pay a use tax.

The current state tax nexus standard was established by the Supreme Court in Quill Corp. v. North Dakota, 504 U.S. 298 (1992). The Quill Court decision dealt with a mail-order company with sales to about 3,000 customers in North Dakota. Quill's physical presence in North Dakota was minimal, consisting of only a few copies of software that was used by some of its customers to make orders and check inventory. The Court found that the company's physical presence in the State was not sufficient to establish nexus for sales and use tax, and acknowledged that the "physical presence test" is somewhat artificial. For that reason, what amount of activity or physical presence is necessary to create nexus is now mostly defined by state statute or case law and thus varies from state to state.

With consumer compliance low and enforcement costs high, most use tax revenues come from business-to-business sales where companies are registered within the states and subject to audits. It is estimated that business-to-business Internet commerce will grow from $\$ 145$ billion in 1999 to $\$ 7.29$ trillion by 2004. (About.com, Inc., 00') Business-to-business Internet sales pose fewer issues regarding sales or use tax collection due to higher compliance rates resulting from audits by taxing authorities. The actual amount of use tax assessed varies from state to state depending on how extensive of an audit program a state maintains.

\section{State Tax Collections and the Future of Internet Sales}

Today, there are approximately 7,600 state and local governments levying sales taxes out of a potential 30,000 jurisdictions. (Hardesty, '99, 19.02(1)(b) According to the United States Census Bureau, state and local governments collected approximately $\$ 237$ billion in sales and use taxes in 1999 , or $24.8 \%$ of all tax revenues generated that year. (U.S. Dept. of Commerce, Dec. '99) Through these funds, state and local governments provide a variety of public services to their residents.

Every state but Alaska, Delaware, Montana, New Hampshire and Oregon imposes state sales and use taxes. It is still too early to predict what the trends are and how these trends will affect state and local government revenues. Currently, government revenues appear to be reaching, or in some cases exceeding, state government predictions for annual budgets. The National Governors' Association and the National Association of State Budget Officers report that for 1998 and 1999, the 50 states, collected \$11.3 billion in revenue surpluses for 1998, and \$7.5 billion in 1999. Surpluses for state sales taxes totaled \$2.3 billion in 1998 and $\$ 2.2$ billion in 1999. (National Governors' Association, '99)

These reports are confirmed by reports published by the National Conference of State Legislatures' (NCSL) analysis of 1999 revenues. At the beginning of 2000, states are "generally in good to excellent fiscal condition." The NCSL report stated that 20 states will exceed initial revenue expectations, and 29 states and the District of Columbia anticipate that revenue collections will be on target with estimates. (National Conference of State Legislatures, '00) Only Louisiana downgraded its original estimate of revenue collections for 2000. As for their ability to provide services, NCSL stated that almost all states' spending will match original budgets and states will have sufficient revenues to meet additional spending needs. (National Conference of State Legislatures, '00)

According to the latest Bureau of Economic Analysis, in 1999, the real GDP in the United States grew $4.1 \%$ and real disposable personal income kept pace, growing at $4.0 \%$. Not only do people have more income, but they are also purchasing more. Real personal consumption expenditures increased at a 5.3\% annual rate during the same period. (U.S. Dept of Commerce, Bureau of Economic Analysis, Mar. '00). Thus it is not surprising to find that state government revenues are meeting or in some cases exceeding expectations despite the potential for untaxed sales of e-commerce. The NCSL's report of the states' good fiscal health, however, does not necessarily mean that e-commerce's growth is having no impact on the level of untaxed sales. The existing state of the economy 
could be the reason for such revenues.

\section{The 1998 Internet Tax Freedom Act}

In October of 1998, the US Congress passed the Internet Tax Freedom Act, which restricts new Internetrelated taxes. The moratorium states (1) there should be no new taxes on Internet access, unless such tax was imposed and actually enforced prior to October 1, 1998 and (2) there should be no multiple or discriminatory taxes on e-commerce. Due to the complexity of Internet taxation, Congress also passed this Act to give legislators time to define "good public policy" for with respect to this issue. The Internet Tax Freedom Act also contains the following provisions:

- A 3-year moratorium of taxes on Internet access. The act prohibits state or local governments from taxing Internet access fees (i.e., the $\$ 19.95$ or so that many Americans pay monthly to access the Internet) from October 1, 1998 until October 21, 2001. A limited "grandfather" clause permits the handful of states that are already taxing Internet access - Connecticut, Wisconsin, Iowa, North Dakota, South Dakota, New Mexico, South Carolina, Tennessee, Texas, and Ohio - to continue to do so if they can demonstrate that their taxes were "generally imposed and actually enforced" on Internet access providers prior to October 1, 1998 [Rogers, '00]. It is important to note that the "grandfather" exception only applies to "taxes on Internet access" and does not apply to multiple or discriminatory taxes on e-commerce (see below).

- A 3-year moratorium on multiple taxes on e-commerce. The Act defines a "multiple tax" as a tax that is imposed by one state or locality on the same e-commerce that is also subject to another tax imposed by another state or locality. Thus, the Act prohibits state or local governments from imposing taxes that would subject e-commerce buyers and sellers to "double taxation."

- A 3-year moratorium on discriminatory taxes on e-commerce. The Act prohibits the application of discriminatory tax collection requirements imposed on out-of-state businesses. The Act defines a "discriminatory tax" as any tax on e-commerce that is not generally imposed and legally collectible by a state or local government on transactions involving similar property, goods, services, or information accomplished through other means. For example, if a state requires a book seller at a retail outlet to collect and pay sales tax, but does not impose the same tax obligations on the seller if the same sale is made over the telephone from a mail-order catalog, then the state is prohibited from imposing collection and payment obligations on the book seller when the transaction occurs over the Internet. In short, therefore, the Act protects goods and services from taxation that are sold over the Internet and that have no comparable offline tax equivalent.

- $\quad$ Establishes the Advisory Commission on Electronic Commerce (ACEC). In collaboration with countries from around the world, the Act charges the ACEC with the task of studying the critical issues of ecommerce and creating uniform tax policy. The commission has now completed its study and submitted its findings and recommendations to Congress. These can be found at www.ecommercecommission.org.

- Declares that the Internet should be free of new federal taxes. The purpose of this provision was to ensure that the moratorium was national in scope and requires agencies of the federal governments to also abide by the terms of the moratorium.

- Declares that the Internet should be a tariff-free zone. This provision asks the President to "seek bilater$\mathrm{al}$, regional, and multilateral agreements" with foreign countries to keep tariff's and discriminatory foreign taxes off of the Internet.

Although the Internet Tax Freedom Act appears straightforward, it raises several questions. Here are a few common ones, followed by answers. 
- Does the moratorium on e-commerce taxes mean that Internet sales are not subject to sales or use taxes? No. In theory, U.S. Internet sales are taxed the same as if they were bought from a catalog, and the tax must be paid if the item is sent to someone in a state in which the selling company has nexus. Otherwise, the buyer usually must pay a use tax. Thus, sales and use taxes are applied to all e-commerce sales in the U.S., except those sales which do not have a comparable offline tax equivalent (e.g., downloadable software). Internet customers are able to avoid taxes by not paying use taxes on items that they bought either from a seller in another state (or overseas where tax is not administered), or from a state that does not have a sales tax. Thus, as a practical matter, Internet sales are not exempt from sales or use taxes; they simply enable buyers to avoid such taxes.

- What does the moratorium cover? For the most part, the Act treats sales over the Internet the same as catalog sales over the telephone. It has no effect on existing sales taxes because the Act does nothing to change current law on remote sales. Thus, all other sales of products and services over the Internet continue to be subject to the normal tax rules imposed by the various states.

- Do businesses that are based in no-sales-tax states have to collect sales taxes? No. If an entire business is located in a no-sales-tax state, then it is not required to collect sales taxes on its retail sales, even if the buyer resides in a state that has a sales tax.

- Must non-U.S. companies collect sales taxes if the items are bought by U.S. customers? No. A company with no physical presence in the U.S., and with owners that are not U.S. citizens or residents, is not required to collect sales or use taxes on products shipped to the U.S. However, as explained in the next section of this paper, this rule changes if the company resides in a country with which the U.S. has a tax treaty. And again, U.S. customers may be required to pay state use taxes on their purchases if they reside in a state that levies such taxes.

- I own an online store in California. If someone from outside the U.S. buys a gift from my online store for someone living in California, must I collect sales tax? Yes. Excluding non-taxing states, retailers must collect sales tax from the buyer if they have nexus in the state to which the product will be delivered. The key to determining whether a seller must impose sales tax is knowing where the goods will be shipped. Since the bought item will be shipped to a location in California, the seller must charge sales tax whether the buyer is a U.S. citizen or not. If this item were shipped to a citizen of another state, then sales tax would not be imposed but the consumer would most likely be liable to pay the use tax of the state to which the items were sent.

Again, it must be noted that the amount of activity or connection that is necessary to create nexus is defined by state statute or case law and, consequently, tends to vary from state to state. Thus, there are exceptions. For example, Amazon.com currently has distribution centers throughout the U.S. yet they are only required to impose sales tax in the state of Washington, where their corporate headquarters are located. Due to the varying definitions and complex agreements among states and businesses, it can be very difficult to define the meaning of nexus, especially with respect to international sales.

\section{International E-Commerce Taxation}

The consequences of Internet taxation become even more complex when dealing with e-commerce sales that cross international borders. This is because a myriad of competing and sometimes inconsistent tax policies, tariff regulations, and alternate tax structures come into play. But because the Internet is an international commercial forum, this is the norm. To be systematic, let us first look at the tax rules governing international sales to US customers, and then look at international tax regulations in general.

As a rule of thumb, a non-US company must collect taxes on sales to US customers if either one of two conditions is met: (1) the company conducts business in a country with which the U.S. has a tax treaty (this includes all of the major trading partners of the U.S.), or (2) the company has a "permanent establishment" in the U.S. The 
term "permanent establishment" generally means that a company must have a place of business or permanent representatives in the U.S.

If the business is not a resident of a "treaty" country, sales to U.S. customers are taxable if the sales are "effectively connected with the conduct of a U.S. trade or business." [Hardesty, "98] Similarly, when a U.S. vendor sells to a buyer in a country with which the U.S. does not have a tax treaty, the U.S. vendor is at the mercy of the domestic tax rules of that country. (Hardesty, '99, 11.05(7)) The U.S. vendor may arrange a transaction through a country that has a tax treaty with the country in question. Nonetheless, taxpayers that reside in non-treaty countries still face uncertainty concerning international taxation.

What about international sales in general? The following sections discuss the core issues concerning international taxation over the Internet. Because non-treaty countries, mostly in the third world, have no set rules concerning e-commerce taxation, the following sections focus on the laws in the OECD Model Tax Conventions and that are observed by all of the major trading partners of North America and Europe-i.e., the places where most ecommerce is conducted.

\section{Internet Sales and the OECD}

The potential impact of international taxation policies on e-commerce raises many questions concerning who is and is not taxed. Policies adopted in this area have important implications on the continued growth of both e-commerce and trade. The international implications of these policies may hinder the ability of small business throughout the world to compete globally and ultimately slow the $\mathrm{p}$ otential growth of e-commerce.

To address these concerns, businesses and governments from around the world are participating in on going discussions held by the Organization for Economic Cooperation and Development (OECD). The OECD, composed of members from 29 countries, was created as a forum to sponsor international discussion concerning all aspects of society. The aim of the OECD's work is to restrain harmful tax practices that undermine the fairness and neutrality of tax systems throughout the world.

The OECD created five Technical Advisory Groups (technology, professional data access, consumption taxes, business profits, and income characterization) to address the issue of taxing e-commerce. To guide the work of the international representatives on these groups, the OECD outlined several basic taxation principles: (OECD '98)

- $\quad$ Neutrality: goods and services should be taxed the same regardless of the mechanism through which these items are sold;

- $\quad$ Efficiency: compliance costs for business and governments should be kept as minimal as possible;

- $\quad$ Certainty and Simplicity: businesses and taxpayers should be able to easily interpret tax compliance obligations;

- $\quad$ Effectiveness and Fairness: taxes should be levied at the appropriate point of sale and the potential for evasion and avoidance should be minimized; and

- $\quad$ Flexibility: tax systems should be able to keep pace with technical and commercial development

It is not clear to what extent these principles can be applied to Internet tax issues in practice. Below are five important areas: web server issues, tax havens, value added taxes, and tariffs.

\section{Web Servers}

A "fully automated Web server" is one that displays information, takes orders, and delivers goods or services over the Internet. An interesting issue arises when a company has no physical presence in a sales-tax- 
collecting country, but conducts business on fully automated web servers that are run by companies that are in such places. Whether a web server in a foreign country results in permanent establishment is an important but difficult topic. Any decision on this issue will determine whether a foreign company will be required to pay tax or not, so future legislation must be neutral and fair so that a standard set of e-commerce rules apply to all business over the Internet.

The OECD has been interested in his issue and recently drafted a revision to Article 5 of the OECD Model Tax Convention, which deals with determining whether or not a company has permanent establishment in a country. The main question is "whether the mere use of computer equipment located in a country through which electronic commerce operations are carried on in that country could constitute a permanent establishment." (OECD, '00)

Article 5 states that a Web server in a country will result in a permanent establishment only if the server is owned or rented by the company that is using the server. Thus, the use of a Web server in a country will not result in a permanent establishment for the company using the Web server. Article 5 finds no permanent establishment where "the server and its location are not at the disposal of the enterprise, even if the enterprise has been able to decide that its Web site should be hosted on a particular server." (OECD, '00) It also acknowledges that the temporary nature of a Web site makes a poor basis for a claim of permanent establishment. Within a few minutes, a Web site can be moved from a server in one country to a server in another.

According to Article 5, a Web server that does not remain in a fixed location will not constitute a permanent establishment. A server must remain in a certain place "for a sufficient period of time" before it will constitute a permanent establishment. Since this amount of time is not specified, future decided cases and rulings will be used to determine whether a period of time in a country is sufficient to result in a permanent establishment.

In addition to the permanent establishment issue is the issue of whether a hosting company should be considered an agent of the client company. Under the Convention, as previously mentioned, a "dependent agent" in a country can result in a permanent establishment in a country when that agent has the authority to enter into contracts on behalf of a foreign company. (Hardesty, '99, 19.04(3)) However, no permanent establishment is created where the hosting company is an "independent agent."

If a Web server of a company, hosted in another country, provides services that enable e-commerce, will the hosting company be an agent that results in permanent establishment? These agents may occasionally enter into agreements on behalf of their foreign clients, but this activity does not cause a permanent establishment to arise because these agents are operating in an independent capacity. (Hardesty, '99, 19.04(3)) However, due to the uncertainty of this issue, companies that do not want a permanent establishment in a country are advised to avoid giving agents the authority to enter contracts on their behalf.

While no conclusions have been reached, many experts are now debating what commercial activities that are conducted with a Web server are taxable. Consensus seems to be building that:

- $\quad$ A Web server that carries advertising for which a company receives a fee may be sufficient to create permanent establishment in the country in which the server is located.

- $\quad$ A Web server in a country that displays advertising or other information will not result in permanent establishment. This is based on the fact that tax treaties among OECD countries exempt from permanent establishment facilities that are merely preparatory or supporting to a company's main business functions. (Reid \& Davidson, '99)

- A fully automated Web server located in a country most likely represents a permanent establishment in a country. For instance, a Web server in a country from which consumers can both purchase and download software, without the participation of human operators, is a fully automated Web server that can cause the Web server's owner to have a permanent establishment in the country in which the server is located. (Hardesty, '99, 19.04(4)) 
With careful planning, a company whose only presence in a country is its Web server will most likely be able to avoid permanent establishment in a country.

\section{Tax Havens}

Tax havens are countries that enable businesses to avoid paying the taxes they would have owed if they operated in their own countries. Thus, a tax haven is a jurisdiction that actively makes itself available for avoiding tax collections. The benefits of doing business in a tax haven include: heavy promotion, low or no taxes, well-developed banking centers, assured secrecy in banking and commercial transactions, freely-exchanged currencies, good transportation, and good telecommunication services. (Doernberg, R. \& Hinnekens, L., '99, 4.2.4)

In many cases, companies can organize an offshore operation without leaving their home country. (To confirm this, simply search the Internet using the keyword "tax haven" and a dozen sites will be displayed offering tax haven establishment.) The newly-incorporated company can also contact local providers in the foreign country to operate a Web server in its behalf, thus enabling it to operate a business.

The profits earned by offshore operations that are sent back to their U.S. or European owners will be taxed at appropriate rates by their home countries. However, for the period of time that profits remain offshore-perhaps indefinitely-they go untaxed. Thus, it is easy to understand why the owners of profitable e-businesses create corporate entities in tax haven areas. It is much harder to understand how such off-shore creations satisfy the OECD's tax principles of neutrality or fairness. This issue is likely to become increasingly important as more businesses take advantage of such tax dodges and estimates of lost or deferred tax collections grow.

\section{Value Added Taxes}

Value added taxes (VAT) are taxes imposed on all levels of production and are based on the increase in value that is added to the good or service by each level. (Encyclopedia.com, '00) Historically, services have been taxed at the service provider's business location. But, as Internet products and services have grown, this VAT system has put European providers at a disadvantage compared to those foreign competitors (such as those in the United States) where VAT taxes are not imposed.

Currently, value added taxes account for almost a fifth of the tax revenues for each of the European Union's (EU) member states, and contributes 44\% of the European Commission's budget. (European Commission, '99, p.2) The European Commission, a subsidiary of the EU, is in the process of adapting its value added taxes (VAT) system to all goods and services, regardless of the medium through which these items are sold. But due to the EU's inability to collect VAT's over the Internet, the European Commission is considering a system of registration for businesses. Under this system, those businesses conducting a certain amount of business within the EU would be required to register with taxing authorities, and to collect and pay VAT taxes to the proper member countries. (European Commission, '99, p.6)

It is no surprise that the main goal of such a proposal is to have U.S. businesses register with the EU tax authorities so that the major U.S. businesses will be taxed. Companies such as Time Warner, Disney, Microsoft, Amazon and Sony should be relatively easy to follow concerning taxing responsibilities. It is most certain that thousands of non-EU businesses will not comply with this proposed requirement. However, these companies will make up only a small part of the market. (Hardesty, '99, 19.03)

\section{Tariffs}

A tariff is a fee that national governments impose on imported goods and whose calculation is based on the country of origin rather than its place of consumption. Unlike other taxes, therefore, tariffs are usually designed less to generate revenues and more to protect domestic industries from foreign competitors. Through customs duties or tariffs, countries impose a differential tax burden at the border, with the effect of disadvantaging imports. 
Imposing tariffs on e-commerce presents a unique situation because electronic transmissions effortlessly cross international borders and can easily include digital products ordered or supplied over the Internet. Examples include software, music, videos, gambling services, pornography products, authentication services, and electronic greeting cards. Unlike physical goods, digitally transmitted products are not readily identifiable in electronic transmissions and certainly do not usually stop at the border. As a result, imposing tariffs on digital products raises several logistical and privacy concerns, and efforts to impose tariffs on them are likely to create heavy enforcement burdens on those nations who have them.

\section{E-Commerce Taxation Arguments}

Many feel that Internet sales should not be tax-free. Others believe that existing tax policies should apply with equal vigor to Internet commerce, and that all economic transactions should be taxed the same, regardless of the form, intellectual content, or place of origin. The following paragraphs outline the arguments both for and against Internet taxation.

\section{Why the Internet Should Be Taxed}

Perhaps the most commonly-cited argument why Internet sales should be taxed is that failing to do so creates unfair advantages for e-commerce firms over main-street businesses. These advantages not only include the benefits that accrue from the ability to sell "cheaper" (i.e.,"non-taxed") products, but also the advantages of simplified record keeping and reporting-hardly tax-neutral policy. The remedy is straightforward: all sales should be taxed equally.

A second argument is the fact that e-commerce is itself big business and that potential tax revenues are likely to be substantial. In the United States, the growth of e-commerce has had a positive effect on state and local government revenues, yet the potential impact of e-commerce on future sales tax revenues is uncertain at this time. A recent study estimates that, in 1999, state and local governments collected $\$ 140$ million in sales and use taxes from business-to-consumer purchases over the Internet, but were unable to collect an additional $\$ 525$ million in sales and use taxes from Internet retail purchases. (Forrester Research, Inc., '00) Future revenue losses for 2003 resulting from business-to-consumer sales are projected to be $\$ 3.5$ billion-less than $2 \%$ of all revenue from sales and use tax collection estimated for 2003-but is still a significant amount of money (Goolsbee, '00).

As e-commerce matures, more sales will be made over the Internet. These sales will ultimately carry over from sales that would have otherwise been made in a "mainstream" store. Considering only $20 \%$ of e-commerce is taxed, revenues will unquestionably be lost. (Forrester Research, Inc., '00) If this were to occur, governments from around the world would have to consider cuts in spending and alternative sources of revenues.

Another concern is the fact that current state sales tax laws vary considerably from state to state. Variations not only include differences in the tax rates themselves, but also on what is and is not taxed. Federal Internet taxes are therefore necessary if for no other reason than to level a now-uneven playing field. This is also important because those firms conducting e-commerce from states with relatively low sales tax rates now have a competitive advantage over those conducting e-commerce in states with relatively high sales-tax rates. This competition now encourages companies to move to low-tax states, pressuring the legislators in high-tax states to reduce sales tax rates. A uniform tax code eliminates these distortions and potential dislocations, simplifies tax collecting, and encourages tax neutrality in the marketplace.

Some scholars also argue that Internet taxes are desirable because they impose taxes on those individuals most able to pay them. The "digital divide" refers to the inequality between individuals with access to a computer and those without such access. This disparity may result from economic, geographic, educational, age, and cultural differences. In a 1999 study by the U.S. Department of Commerce's National Telecommunications and Information Administration (NTIA), people with a college degree are over eight times more likely to have a computer than those who are less educated. At present therefore, the higher-income households that can afford computers and modems are the major beneficiaries of the tax loopholes the Internet now provide s. 
Conversely, proposals to eliminate taxes on e-commerce penalize low-income taxpayers. Low-income taxpayers are the least likely to have Internet access and buy goods online. Exempting online purchases from taxes would benefit wealthy taxpayers and shift part of their tax burden onto low-income consumers who buy goods in stores where taxes will continue to be collected.While the Internet is providing new avenues for communication, learning, and commerce, there is a substantial gap between those participating and those who are not. [U.S. Dept. of Commerce, July '99] Over $60 \%$ of those with a college education use the Internet as opposed to only about $7 \%$ for those with a high school degree or less. (U.S. Dept. of Commerce, July '99) NTIA's research also describes a growing divide for in home Internet access among minorities, with an increase in the gap between Caucasian and African-American households of $37.7 \%$ and an increase by $37.6 \%$ between Caucasian and Hispanic households between 1997 and 1998. (U.S. Dept. of Commerce, July '99) Fortunately, the NTIA study did report some encouraging news; the report reveals a $50 \%$ overall increase in Internet usage, regardless of income, race or national origin. (U.S. Dept. of Commerce, July '99).

\section{Why the Internet Should Not Be Taxed}

Many scholars support the idea that the Internet should be an international tax-free zone. One compelling argument is that the Internet was created to foster the free exchange of information electronically. Taxing sales on the Internet violates this fundamental objective and is thus philosophically anathema to those who use it. Such authorities also note that most Internet consumers pay shipping and handling fees that often more than offset any salestax savings, and that any brick-and-mortar company can compete with an Internet competitor simply by creating its own web site for this.

As a practical matter, tax scholars note that collecting and enforcing taxes and tax laws on the Internet is unreasonable-i.e., complex, unwieldy, inefficient, and expensive. Enforcement costs include defining what is taxable, determining applicable tax rates, identifying exemptions, updating rates changes, ensuring privacy, auditing collections, and prosecuting violators. Although the totality of these costs is uncertain, a study conducted by Ernst \& Young suggests that the administrative costs of enforcing Internet sales taxes are likely to consume most of the anticipated revenues [Cline \& Neubig, '99]. In particular, according to the study, the cost of collections, as a percentage of tax collected, was $87 \%$ for small firms $(\$ 250,000-\$ 750,000$ in sales), $48 \%$ for medium sized firms $(\$ 750,000$ - \$10 million in sales), and 14\% for large sized firms (over \$10 million in sales).

The Unites States alone has over 7,600 state and local governments levying sales taxes. If all Internet transactions were taxed, multiple, overlapping, and discriminatory taxes are likely to occur, and imposing such a tax system is likely to harm Internet commerce. Further, almost every industry is now engaged in some form of ecommerce or has initiated Internet based services. Imposing burdensome taxes on e-commerce would discourage further efforts in this regard and likely slow innovation, job creation, and economic growth in general.

It is also possible to argue that creating Internet taxes is likely to require a substantial increase in government tax supervision and enforcement efforts. An argument against Internet taxation is the cost of compliance and enforcement. The inherent difficulties in achieving compliance with the sales and use tax systems of almost 7,600 state and local tax jurisdictions is unimaginable. It would be impractical for government to enforce collection of tax on remote sales by chasing after the purchaser and the cost to collect use tax directly from consumers would far exceed the total amount collected. Tax collection agencies at all levels of government would grow larger and more intrusive as efforts to tax e-commerce proliferated.

Because state and local revenues are currently meeting or exceeding expenditure needs, tax planners reluctantly admit that at present, there is no hint of a revenue crisis facing the states. Similar comments apply to most of the U.S. trading partners. Thus, with overly-sufficient revenues pouring in, it cannot credibly be argued that ecommerce is currently undermining the ability of nations to provide needed social and economic services. In addition, the Internet will not take over main street businesses because local stores cater to a customer's desire for a hands-on experience. Shopping is for many people a pleasurable social experience that cannot be duplicated online. Thus, Internet sales won't destroy retailers, just as catalog sales haven't. The human factor still drives shopping. 
In addition to the above arguments, there are no signs that our current e-commerce tax policy is not working. Taxes are being applied to purchases over the Internet, though there have been no reports of significant loss due to taxation of sales over the Internet.

A final argument against Internet taxation is that such tax rules have the potential to violate individual rights to privacy. Certainly, there are many purchases that can be made over the Internet that are personal in natureinformation. Technological advances will likely allow for increased tax collection efficiencies. Thus, a concern is that the need to maintain records of Internet tax collections for taxing authorities simultaneously creates a $\log$ of individual tax payments and thus disables a tax payer's ability to remain an anonymous consumer agent. Anti-tax proponents argue that such intrusion invades personal privacy and creates an unreasonable and differential recordkeeping burden on companies with Internet sales.

\section{Summary And Conclusions}

Perhaps the only thing that is not controversial about taxing Internet commerce is the statement that it is so. E-commerce sales raise new issues for taxing systems throughout the world. An international perspective is necessary to address this subject since e-commerce potentially crosses national borders to a greater extent than other, traditional forms of doing business. Every nation must give serious consideration to the impact on its trading partners from any new rules for taxation of e-commerce. Any tax-administering system for e-commerce should be developed in a manner that minimizes disclosure of consumers' personal information and should contain sufficient security to protect that information. We must explore privacy issues involved in the collection and administration of taxes on ecommerce, with special attention given to the repercussions and impact that any new system of revenue collection may have.

Though the issues of e-commerce taxation are unsettled, we must begin discussion that will lead to the significant simplification and reform of current tax systems if they are continue to remain viable in the future. This new international tax system must be designed to enable all consumers to enjoy the benefits of efficiency, simplicity and fairness. The OECD is the appropriate forum to sponsor the essential international dialogue, which will require a contribution from business communities from around the world.

\section{References}

1. About.com, Inc., “A Beginners Guide to B2B Electronic Commerce," September 9, 2000 http://ecommerce.about.com/smallbusiness/ecommerce/library/weekly/aa021600a.htm.

2. Cline \& Neubig, "Masters of Complexity and Bearers of Great Burden: The Sales Tax System and Compliance Costs for Multistate Retailers," September 8, 1999. http://www.ey.com/global/vault.nsf/us/Masters_of_Complexity/\$file/complexity.pdf.

3. Doernberg, R. \& Hinnekens, L., "Electronic Commerce and International Taxation," Kluwer Law International, December 1998, 4.2.4.

4. $\quad$ Encyclopedia.com, "Results for value-added tax," August 10, 2000 http://www.encyclopedia.com/articles/13330.html.

5. European Commission, "Harmonization of Turnover Taxes Working Paper," June 8, 1999, p. 2-6 http://europa.eu.int/comm/taxation_customs/publications/working_doc/taxation/ecommerceEN.pdf.

6. Forrester Research, Inc., "States Lose Half a Billion in Taxes to Web Retail," February 24, 2000 http://www.forrester.com.

7. Goolsbee, Austan, "In a World Without Borders: Impact of Taxes on Internet Commerce," Quarterly Journal of Economics, May 2000

8. Hardesty, David, Electronic Commerce: Taxation and Planning, (Warren Gorham \& Lamont, Dec. 99)

9. Hardesty, David, "Internet-Based Sales to the United States," October 28, 1998

http://ecommercetax.com/doc/122898.htm.

10. Internet Tax Freedom Act, 47 U.S.C. § 151, 1998

11. National Conference of State Legislatures, Fiscal Affairs, "State Fiscal Outlook for 2000,” Jan. 5, 2000 
http://www.ncsl.org/programs/fiscal/sfo2000.htm.

12. National Governors' Association, "Fiscal Survey of States," Dec. 1999 http://www.nasbro.org/side.htm Nau Internet, "How Many Online," July 2000 http://www.nua.ie/surveys/how_many_online.

13. OECD, "A Borderless World - Realizing the potential of Electronic Commerce," Oct. 8, 1998 http://www.oecd.org//daf/FSM/ecomfrawrkconden.html.

14. OECD, Committee on Fiscal Affairs, "Proposed Clarification of the Commentary on Article 5 of the OECD Model Tax Conventions, Draft for Comments," 2000 http://www.oecd.org/daf/fa/first_en.htm

15. Quill Corp. v. N. Dakota, 504 U.S. 298, 1992.

16. Reid \& Davidson, "The E-Commerce Dialogue Continues," Tax Planning International E-Commerce, January 1999.

17. Rogers, Amy, "House approves extension of Internet taxation moratorium," Computer Reseller News, May $15,2000$.

18. U.S. Dept. of Commerce, Bureau of the Census, "Quarterly Summary of State and Local Tax Revenue," December 1999 http://www.census.gov:80/govs/www/qtax.html.

19. U.S. Dept. of Commerce, Bureau of the Census, "Retail E-Commerce Sales for The Fourth Quarter 1999 Reach \$5.3 Billion,” March 2000 http://www.census.gov/Press-Release/www/2000/cb00-40.html.

20. U.S. Dept. of Commerce, Bureau of Economic Analysis, "Business Situation," March 2000 http://www.bea.doc.gov/bea/an/bsback/0300/maintext.htm.

21. U.S. Dept. of Commerce, National Telecommunications and Information Administration, "Falling Through the Net: Defining the Digital Divide,” July 1999, rev. Nov. 1999

http://www.ntia.doc.gov/ntiahome/newitems/urb-rur.txt.

Notes 